\title{
EFFECTS OF REFINERY EFFLUENT ON THE PHYSICO-CHEMICAL PARAMETERS OF STREAM WATER.
}

L. UYIGUE

(Received 30 July 2001; Revision accepled 14 December 2002)

\begin{abstract}
ABSTRRACT
Managing oil and gas industrial environment requires constant monitoring of the effluent discharges from such industries. The essence of such monitoring is to ascertain the level of compliance of such industries with the pollution control guidelines set by regulating agencies.

In this work, the effects of refinery effluent discharge on the physico-chemical paraneters of the stream water has been studied, using treated effluent water discharged from the Port Harcourt Refinery into the Ekerekana Creek in Okrika as reference. Samples were collected at the discharge point into the Creek and subsequently at 500 metres and 1000 metres down stream:

The samples were analysed for physico-chemical parameters such as $\mathrm{pH}$, TDS, TSS, COD, Oil and Grease, Temperature, Cations $\left(\mathrm{Pb}^{2+}, \mathrm{Fe}\right.$ (total), $\mathrm{Cu}^{2+}, \mathrm{Cr}^{6+}, \mathrm{Ca}^{2+}$, and $\mathrm{Mg}^{2+}$ ) and Anions ( $\mathrm{PO}_{4}^{3}, \mathrm{NO}_{3}$, $\mathrm{SO}_{4}^{2-}$ and $\mathrm{Cl}$ ). The results showed that Oil and Grease, COD, Cations $\left(\mathrm{Pb}^{2+}, \mathrm{Fe}(\right.$ total)) and temperature were affected by dilution, and are stated as follows: oil and grease, 24 to $7 \mathrm{mg} / \mathrm{l}$; Iron (Fe (total)), 1.0 to $0.16 \mathrm{mg} / \mathrm{l}$; lead $\left(\mathrm{Pb}^{2}{ }^{\prime}\right), 0.035$ to $0.006 \mathrm{mg} / \mathrm{l} ; \mathrm{COD}, 7$ to $1 \mathrm{mg} / \mathrm{l}$ and temperature, 24.1 to $22.0^{\circ} \mathrm{C}$.
\end{abstract}

Keywordis: Effluent water, Concentration, Dilution, Physico-chemical parameter, Pollutant.

\section{INTRODUCTION}

Effluent water is often referred to as produced or waste water; such water contains fundamentally some quantity of substances in such a concentration that makes the water technically polluted (Madian et al, 1994). The sources of this water in the oil and gas industries comes from oil bearing formations, oil reservoirs and crude oil storage tanks. Other miscellaneous sources includes liquid discharges from production operations, accidental oil spills from leakages, deck drainages, and sour water stripper condensate. Others are contaminated process water, desalter water, caustic water and oily water from ships ballast (Jamaludin and Vandamme, 1994).

For about three decades now, the Niger Delta environment has experienced degradation due mainly to the discharge of noxious effluents both at fugitive points and pipe ends, by oil and gas industry operators. In the wake of a renewed environmental awareness on the negative impacts of such discharges on the environment, there is need to regularly assess the effluents so discharged. The essence of such assessment is to ascertain the level of compliance with the pollution control regulation, governed by the principal legislation of the Petroleum Act (1969) and enforced in Nigeria by the department of petroleum resources (DPR) and the federal ministry of environment (DPR, 1991).

Effluent water, if not treated will have some adverse effects on aquatic life, inhabitants and farmlands. It has been reported that heated effluent water increases the temperatures of the receiving river water body, leading to increased oxygen consumption of fish for metabolic processes, thereby decreasing oxygen concentration in water. The swimming speed of some fish species declines at higher temperatures, hence $19^{\circ} \mathrm{C}$ makes them

L. UYIGUE, Department of Chemical Engineering, University of Port Harcourt, Choba, Port Harcourt. 
susceptible to predators and consequently reduces fish resistance to diseases (Harrison, 1990).

The presence of nitrogen and phosphorus in effluent water discharge has been found to encourage algae growth and presence of hydrocarbon can cause bacterial and fungal growth. This may lead to reduction in the population of plankton and undesirable fish infestation (Elf, 1993, Hilde and Stale, 1994).

The consumption of effluent water leads to infected concentration of heavy metal in human systems causing metabolic malfunctions. These metals are cadmium, chromium, mercury and lead. Also the consumption of fishes infected with mercury may result in the minamata disease. (Nwankwo and Irrechukwu, 1991).

Taste and odour of water contaminated with effluent water are usually found to be objectionable due to the presence of soluble hydrocarbons. Consequently. Mckee (1972) predicted the solubility of modern gasoline in ground water to be in the range of 20 to 80 $m g / l$. The water was however found to be tasty at solubility range of $0.005 \mathrm{mg} / \mathrm{l}$ to $0.5 \mathrm{mg} / \mathrm{l}$. Nitrate also produces bitter taste in polluted water and may cause methemoglobinemia in infants under six months (Ajao et al, 1991).

Oil remains a major effluent water pollutant when discharged on farmland. It increases aeiobic condition in soil, thus reducing soil oxygen content. Hence transpiration and evaporation from soil is drastically reduced (Toogood and Rowell, 1977). Associated vegetation also show peculiar symptoms of leave yellowing, total chlorosis, premature abscission and necrotic spots. (Odu, 1981).

The $\mathrm{pH}$ value of the polluted soil may increase and brings it to neutral level irrespective of original status. Increase in the pollutant level may decrease the phosphorus level as in the case of Obagi. Total nitrogen may increase as well as potassium whilst calcium decreases (Elf, 1992).

Previous works done on physico-chemical analysis are widely reported in the literature but notable ones in the Niger Delta area are those of Obagi Creek and the Upomami flow slation respectively (Elf, 1992, 1994). In the latter. three sampling points (SP1, SP2 and SP3), each 500 metres apart on the Upomami Creek were used for the study. The results showed that lead ions $\left(\mathrm{Pb}^{2+}\right)$, TSS, $\mathrm{pH}$, Turbidity and TDS responded positively to dilution while other parameters, such as Copper ions $\left(\mathrm{Cu}^{2+}\right)$, Zino ions $\left(\mathrm{Zn}^{2+}\right)$, Chromium ions $\left(\mathrm{Cr}^{6+}\right)$, Total iron $(\mathrm{Fe}), \mathrm{COD}$ and $\mathrm{BOD}$ exhibited partial-dilution (Elf, 1994).

Effluent water from Obagi flow station was analysed for physico-chemical parameters such as Turbidity, BOD, COD, ammonium ions, oil and grease, phenolic compounds, salinity, TSS and total iron. The results showed that TSS and total iron exceeded their DPR limits (Elf, 1992).

\section{EXPERIMENTAL}

Prior to water sample collection the following controlling factors were noted, they are existing water quality, the rate of mixing, dilution, dispersion and the tidal influence.

Great dilution of the discharge effluent is expected at high tides than at low tides. Thus Ekerekana Creek is under tidal influence, it comes at about $4 \mathrm{pm}$ daily and return at night. The time of sample collection was when the tide was returning.

Samples were obtained at surface level from three linear points along the Ekerekana -. Okrika Creek. One is at the effluent discharge point (WSP1), the second at 500 meters away from discharge point (WSP2) and another at 1000 meters away from discharge point (WSP3). While WSP1 is to serve as control.

Collected samples from these three points were analysed in accordance with the department of petroleum resources (DPR) recommended test methods for physico-chemical parameters (DPR, 1991).

The physical parameters measured were sample $\mathrm{pH}$ and sample temperature using the $\mathrm{pH}$ meter. The $\mathrm{pH}$ meter was standardised using a buffer solution of $\mathrm{pH} 4,7$ and 10 . The $\mathrm{pH}$ 
olectrode was washad with distillod waler antel immadiately limmersad in a baker containing the sample. The roadings were taken from the ply motar (inaluding the sample temporature).

The total dissolved solid (TDS), total suspended solid (TSS), alvemical oxygen demand (COD) and oil and grassa ware meastred by the chemical methods discussad here under.

\section{(a) Total dissolved solid (TDS)}

A porcelain dish was dried at $100^{\prime \prime} \mathrm{C}$ in an oven for one hour and $50 \mathrm{mls}$ of sample was filtered into the pre:weighed porcelain dish using Q 0.45 micron mambrane filter

The filtrate in the weighed porcelain dish was ovapurated to dryness using an evaporating bath and the porcolain was driod again in the oven at $105^{\circ} \mathrm{C}$ for another one hour. The porcelain was subsequently reweighed.

TDS $(\mathrm{mg} / 1)=$ (\{weight of porcelain + Residue $)$ - (weight of porcelain) $\times 10^{6}$

\section{Volume of sample}

Precision $= \pm 0.001$

\section{(b) Total Suspended Solid (TSS)}

With the aid of forceps, faintly marked membrane filter papers were dried in an oven at $105^{\circ} \mathrm{C}$ for one hour and placed in a dessicator to cool for another one hour. The membrane filter papers were weighed and weight recorded.

The weighed membrane filter paper was placed into a membrane filter paper holder and subsequently soaked with cleaned distilled water and tightened with the Millipore spanners. $50 \mathrm{mls}$ of sample was filtered using the 0.45 micron membrane filter and the membrane filter is further dried in an oven at $105^{\circ} \mathrm{C}$ for an hour, and placed in a dessicator for another one hour and reweighed.

TSS $(\mathrm{mg} / \mathrm{l})=($ (weight of 0.45 membrane filter

+ Residue) -(weight of 0.45 membrane filter) ) $\times 10^{6}$ (c) Dil and Greaso

260mis of anmple was masuroct into it separating fumel and $50 \mathrm{mls}$ of $x y$ land was addod. 'The mixture was thoroughy shakenge so as to anablo xylang mix with oil and gresese.

The waler was decanted, whilo the xylanawoil and grease mixture was ran into a glass tubse. The xylonogil and trobse mixture was ontrifuged for pominutes andel allowed lo sool. The sample was read ill a speotrophotometer in percontugn. From the percantage, absorbanog was read out in a thath and the concentration in parts per million (purn) was determined from the graph.

Oil r groase $(m y / l)$

ppm $x$ (vetume of oil and grease $+x y$ lene mixture) Volume of sample

Precision $\cdots 1.0 .001$

(d) Chemical Oxygen Demand (COD)

$10 \mathrm{~m} / \mathrm{s}$ of sample was homogenised for 5 minutes and $0.2 \mathrm{ml}$ was pipetted out into the COD vial. The cap was replaced tightly and the COD vial rinsed with distilled water and inverted several times for sample to mix with the vial.

The sample in the COD vial was heated in a COD reactor for one hour and removed to cool for another one hour also. The sample was taken to Hach DP/2000 for reading.

Precision $= \pm 0.001$

(e) Cations and Anicns

The concentrations of cations and anions in the sample were measured using the Direct Reading spectrophotometer (Hach DR/2000). The operation was based on program numbers and specific wavelengths using different powdered tablets.

\section{RESULTS AND DISCUSSION}

The results of the effluent water analysis

Precision $= \pm 0.001$ 


\begin{tabular}{|c|c|c|}
\hline Cntions/Anions & $\begin{array}{l}\text { Pyogram } \\
\text { Number }\end{array}$ & $\begin{array}{l}\text { Wavelength } \\
\text { (nim) }\end{array}$ \\
\hline l.cad ions ( $\left(b^{2}\right)$ & 280 & 575 \\
\hline Copper ions (Cu") & 1.35 & 560 \\
\hline Total lron (lie) & 26.5 & 26,5 \\
\hline Clnomiun ions & )() & 540 \\
\hline$\left(\left(r^{n+1)}\right)\right.$ & 160 & 800 \\
\hline Calcium ions $\left(C^{21}\right)$ & 1.50 & 850 \\
\hline $\begin{array}{l}\text { Magnesium ions } \\
\text { (Mlg") }\end{array}$ & $\begin{array}{l}490 \\
780\end{array}$ & $\begin{array}{l}890 \\
620\end{array}$ \\
\hline $\begin{array}{l}\text { Phosphate ions } \\
\left.\text { (Po }{ }_{4}^{3}\right)\end{array}$ & $\begin{array}{l}355 \\
245\end{array}$ & $\begin{array}{l}500 \\
550\end{array}$ \\
\hline $\begin{array}{l}\text { Sulphate }\left(\mathrm{SO}_{4}^{2-*}\right) \\
\text { Nitrale }\left(\mathrm{NO}_{3}^{-}\right) \\
\text {('hloride }(\mathrm{Cl})\end{array}$ & & \\
\hline
\end{tabular}

are presented in the table and figures. Table 1 shows the results of the physical and chemical parametric measurements for surface water samples obtained from the three sampling points. Also shown in table 1 are the DPR compliance limits for inland and near shure areas.

Also, the spatial distributions of the surface water pliysico-chemical parameters for some selected parameters are presented in the figures. Figure 1 shows however, that temperature, chemical oxygen clemand (COD), oil and grease are affected by dilution while $\mathrm{pH}$ is

Precision $= \pm 0.0001$

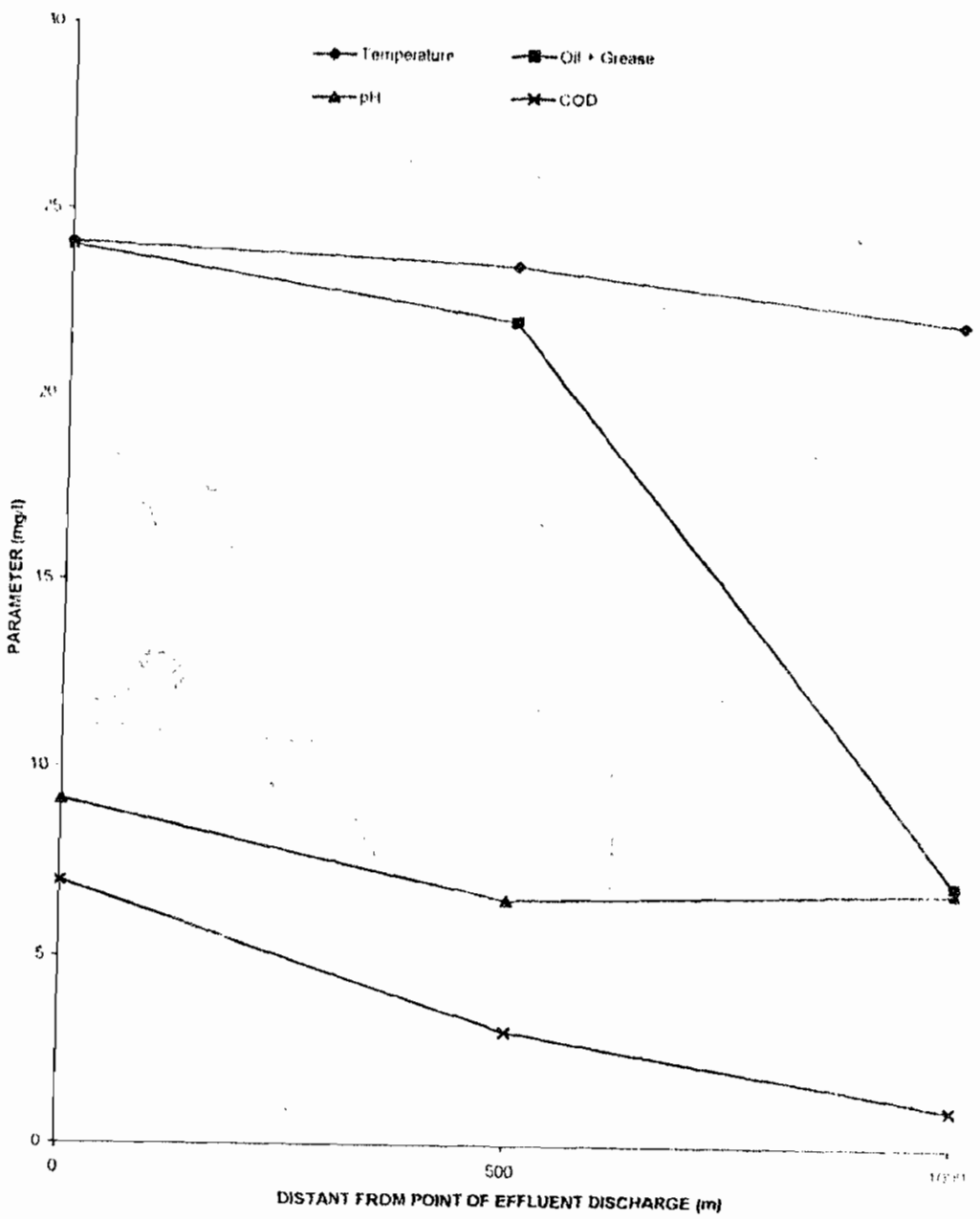




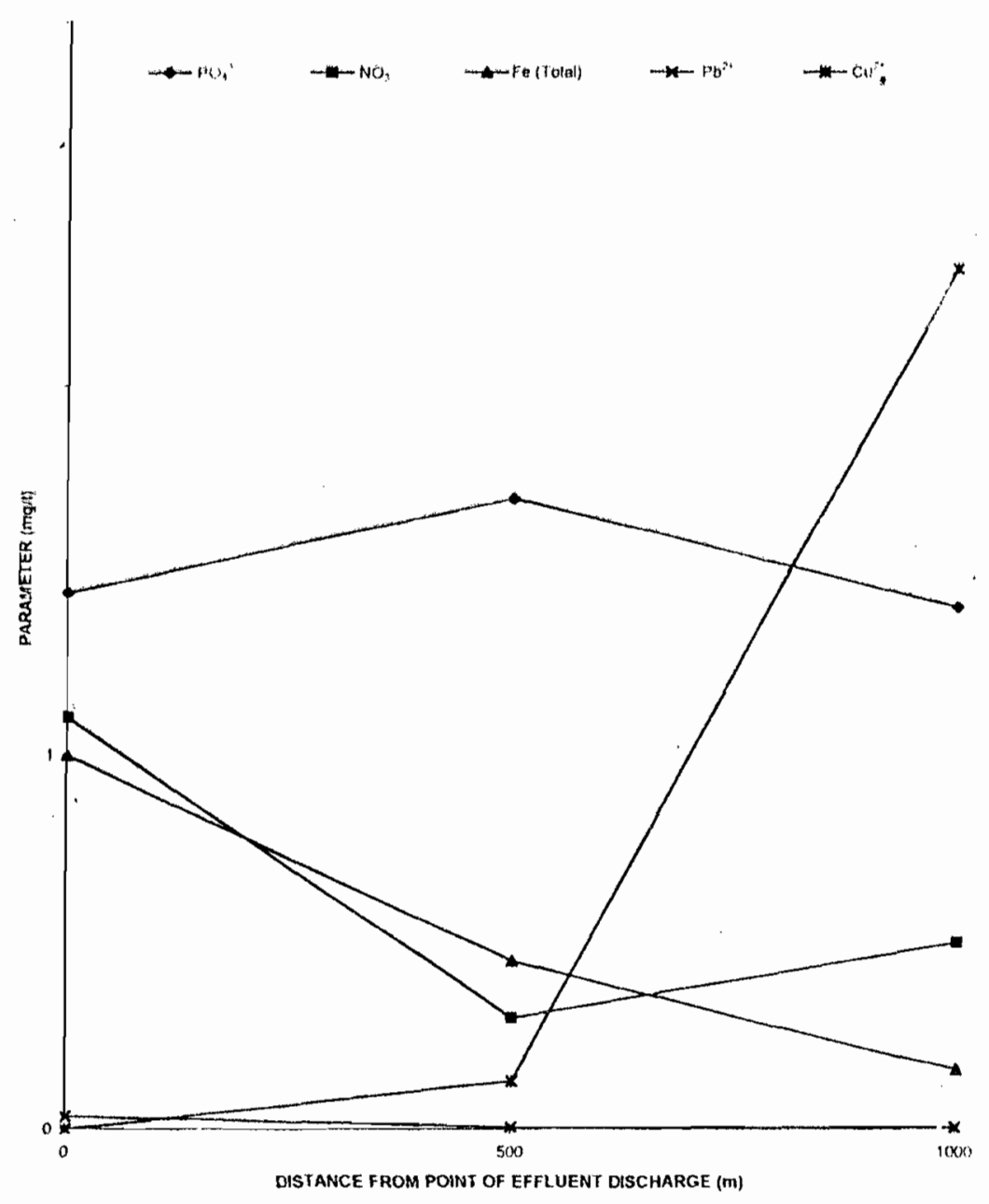

FIGURE 2: SPATIAL DISTRIBUTION OF SELECTED CHEMICAL. PARAMETERS MEASURED AWAY FROM POINT OF EFFLUENT DISCHARGE

unaffected. The reason being that, the receiving stream water apart from being mildly acidic, hydrogen ion $\left(\mathrm{H}^{+}\right)$concentration remains constant no matter the volume of the water.

Figure 2 shows that Total iron (Fe) and lead ions $\left(\mathrm{Pb}^{2+}\right)$ are affected by dilution while nitrates $\left(\mathrm{NO}_{3}^{-}\right)$and phosphates $\left(\mathrm{PO}_{4}^{3-}\right)$ may be said to be partially diluted since the concentration at $500 \mathrm{~m}$ sample point is lower than that at $\mathrm{Om}$ sample point. Copper ions $\left(\mathrm{Cu}^{2+}\right)$ is however unaffected by dilution. Figure
3 shows that chloride $\left(\mathrm{Cl}^{-}\right)$, magriesium tons $\left(\mathrm{Mg}^{2+}\right)$, calcium ions $\left(\mathrm{Ca}^{2+}\right)$ and sulphate ( $\left.\mathrm{SO}_{4}^{2-*}\right)$ are undiluted.

The increased concentrations (undilution) for some of these parameters may be due to the presence of slightly soluble residual impurities in the receiving stream water body, arising from leaching due to stream water contact with rocks and soils as well as human excreta and salt water intrusion, as in coastal areas Harrison, 1990). The possible implication of this 


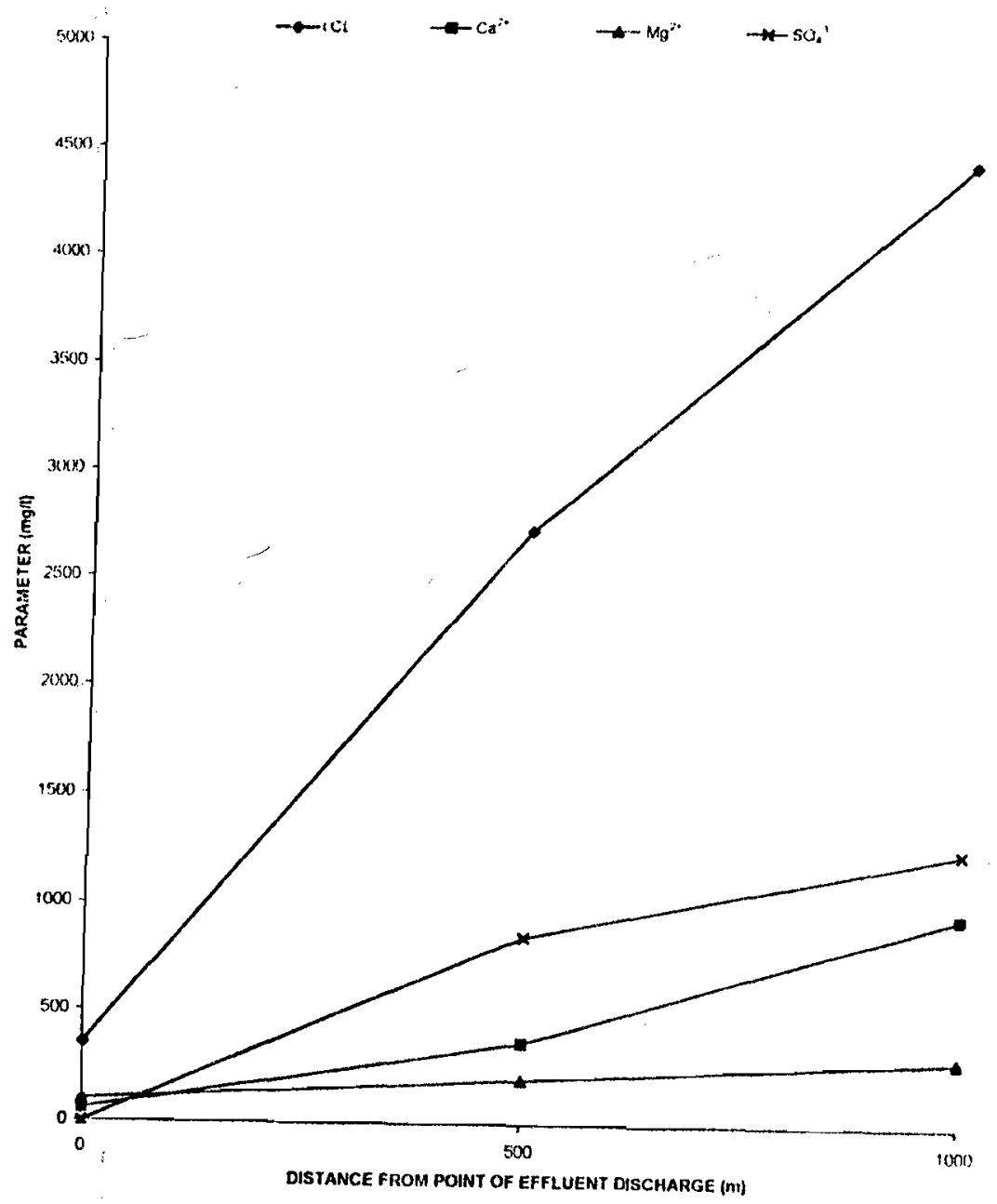

FIGURE 3: SPATIAL OISTRIBUTION OF CHEMICAL PARAMETERS MEASURED AWAY FROM POINT OF EFFLUENT DISCHARGE

phenomenon is a severe environmental problem such as hardness of water.

Apparently therefore, the results of this work obtained in the table and figures are at variance to the findings for Obagi Creek and Upomami flow station (Elf, 1992, 1994) except for total iron (Fe) that responded positively to dilution for both Ekerekana and Obagi Creek.
This variance may be due to existing water body quality for the different creeks.

Consequently, the undiluted physicochemical parameters (see table 1) of the effluent discharge along the creek such as $\mathrm{pH}$, total dissolved solid (TDS), total suspended solid (TSS), calcium ions $\left(\mathrm{Ca}^{2+}\right)$, magnesium ions $\left(\mathrm{Mg}^{2+}\right)$ and chloride $\left(\mathrm{Cl}^{-}\right)$may be apparently due 


\begin{tabular}{|c|c|c|c|c|c|c|}
\hline \multirow[t]{2}{*}{ S/No } & \multirow{2}{*}{$\begin{array}{l}\text { PARAME'TEIRS } \\
\text { (A) Physical }\end{array}$} & \multicolumn{2}{|c|}{$\begin{array}{l}\text { DPR COMPLIANCE. } \\
\text { IIMTS MAXIMUMI FOR } \\
\text { ANY CONSERVATIVE } \\
\text { 30-DAY PERIOD }\end{array}$} & \multirow[t]{2}{*}{$\begin{array}{l}\text { WSEI } \\
(0 \mathrm{~m})\end{array}$} & \multirow[t]{2}{*}{$\begin{array}{l}\text { WSP2 } \\
(501 / 211)\end{array}$} & \multirow[t]{2}{*}{$\begin{array}{l}\text { WSP 3 } \\
\text { (1001) }\end{array}$} \\
\hline & & $\begin{array}{l}\text { Inland } \\
\text { Area }\end{array}$ & $\begin{array}{l}\text { Near shore } \\
\text { Area }\end{array}$ & & & \\
\hline 1 & pli & $6.5-8.5$ & $6.5-8.5$ & 9.16 & 6.54 & 6.8 \\
\hline \multirow[t]{2}{*}{2} & Temperature ("C) & 35 & 40 & 24.1 & 23.5 & 22.1 \\
\hline & B(i) Chemical & & & & & \\
\hline 3 & $\operatorname{TDS}(m g /)$ & 2000 & 5000 & 2360 & 13,120 & 22,220 \\
\hline 4 & $\operatorname{TSS}(\mathrm{nug} / \mathrm{l})$ & 31) & 50 & 154 & 176 & 316 \\
\hline 5 & $\begin{array}{l}\text { Oil and Grease } \\
(\mathrm{mg} / \mathrm{l})\end{array}$ & 10 & 20 & 24 & 22 & 7 \\
\hline \multirow[t]{2}{*}{6} & COD & 40 & No limit & 7 & 3 & 1 \\
\hline & (ii) Cations & & & & & \\
\hline 7 & $(1)^{2+}(\mathrm{mg} / \mathrm{l})$ & 0.05 & $\therefore$ imimit & 0.035 & 0.0117 & 0.0116 \\
\hline 8 & Fe (lotal) (1)g/l) & 8,60 & $-d t i-$ & 1,00 & 0.45 & 0.16 \\
\hline 9 & $\mathrm{Cu}^{i+}(\mathrm{mg} / \mathrm{l})$ & 3.5 & $-\mathrm{da}=$ & No & 0.13 & 2.32 \\
\hline io & $\operatorname{Cr}^{6+}(\mathrm{ng} / \mathrm{l})$ & 0.03 & $-d a=$ & ND & NI) & NII \\
\hline 11 & $\mathrm{Ca}^{2}(\mathrm{mg} / \mathrm{l})$ & 2011 & -10 & 100 & 2011 & 300 \\
\hline \multirow[t]{2}{*}{12} & $\mathrm{Mg}^{2+}(\mathrm{mg} / \mathrm{l})$ & 150 & dro. & 60 & 36.4 .5 & 951.71 \\
\hline & (iii) Injons & & & & & \\
\hline is & $\mathrm{PO}^{\prime}(\mathrm{mg} / \mathrm{l})$ & 20 & No limit & 1.43 & 1.69 & 1.39 \\
\hline 14 & NO, (mg/l) & 50 & $-d a$ & 1.1 & 0.3 & 0.5 \\
\hline is & SO $=(\mathrm{mg} / \mathrm{l})$ & 400 & $-\pi$ & $* 0.011$ & 856 & 1250 \\
\hline 16 & CI (mg/l) & 6019 & $-d o$ & 355.06 & 2728.01 & 4451.53 \\
\hline
\end{tabular}

NO'TE: $\quad$ NU = NOT DETECTED

to the presence of residual pollutants in the Ekerekana creek.

\section{CONCLUSION}

The reduction in concentration of physico-chemical parameters such as lead iors $\left(\mathrm{Pb}^{2+}\right)$, phosphate $\left(\mathrm{PO}_{4}^{3-}\right)$ and nitrate $\left(\mathrm{NO}_{3}\right)$ along the creek surface to such a level lower than the DPR compliance limits, indicates that the Ekerekana creek has very low potenial for the above parameters.

The unusual increase in the concentrition of other physico-chemical parameters such as; TDS, TSS, calcium ions $\left(\mathrm{Ca}^{2+}\right)$, magnesium ion: $\left(\mathrm{My}^{2+}\right)$, sulphate $\left(\mathrm{SO}_{4}^{2-\cdots}\right)$ and chloride ions $(\mathrm{Cl})$ along the creek surface may be attributed to existing residues of these impurities at Ekerekana Creek water body.

Consequently, the effluent water discharge from the Port Harcourt Refining Company (PHRC) may be sald to be of acceptable quality than that of the creek.

NOMENO I ATIIRL:

\begin{tabular}{|c|c|c|}
\hline DPR & $\therefore$ & Department of Petrolecum \\
\hline $\operatorname{los}$ & $\therefore$ & Total Lissolved Solid \\
\hline$\$ 11$ & $\cdots$ & Sample Point one \\
\hline $\mathrm{SP} 2$ & $\therefore$ & Sample Point I'wo \\
\hline $\mathrm{SP3}$ & $\therefore=$ & Sample Point Three \\
\hline ISS & & Tolal Suspended Solid \\
\hline$(y)$ & $=$ & Chemical Oxygen I Rema \\
\hline
\end{tabular}




$\begin{array}{lll}\text { BOD }= & \text { Biological Oxygen Demand } \\ \text { WS }= & \text { Water Sample } \\ \text { WSP1 }= & \text { Water Sample Point One } \\ \text { WSP2 }= & \text { Water Sample Point Two } \\ \text { WSP3 }= & \text { Water Sample Point Three } \\ \text { DR }= & \text { Direct Reading } \\ \text { SPL }= & \text { Society of Petroleun Engincers } \\ \text { PIRC }= & \text { Port Harcourt Refining Company Linited. }\end{array}$

\section{REFERENCES}

Ajao, E. A., Oyewo, E. O. and Orekoya, T., 1991. The Elfect of Oil Formation Walter on some Marine Organisms. SPE Conference Proceedings. 80-81.

Department of Petroleum Resources (DPR). |99|. Environment Guidelines and Standards for t..e Petroleum Industry in Nigeria. Ministry of Petroleum Resources, Lagos. 5 - 120.

E1f Petroleum Nigeria Limited. 1994. Effluent Water sampling and Monitoring of Physico-chemical Parameters at Upomani Creek and Discharge Point. $1-15$.

Eli Petrolenm Nigeria Limited. 1992. Effluent Water sampling and Monitoring of physico-chemical Paraneters at Obagi Flow Station. 1-20.

Elf Petroleum Nigeria Limited. 1993. Environmental Evaluation Report for Odhiage Spillage Point. (OML-58). Vol . I \& 11. 15-42.
Harrison, R.M., 1990. Pollution: Causes, Effects and (mutu. Royal Society of Ciscmistry, Cambridge. R. II Harrison $2^{\text {nd }}$ Edition. 99-125.

Hilde, R. and Stale, J., 1994. Determination of produced walls contaminants in the marine enviromment. SPE Jakarka 27151:479-484.

Jamaludin, A.K.N. and Vandamme, L.M. 1994. Produced Water Management in the Canadian Petrolem Induslry. SPE Jakarta. 27133; 353-364.

Madian, E.S., Tarwanto, M., Snavely, E.S. and Jan. R.I. 1994. Treating of Produced Water and the Gian" Arun Field. SPI . Iarkata. 27130: 335-34.4.

McKee, J.L. 1972. Gasoline in Ground Water. Joumal of Water Pollutant Control Federation. 44: 293-302.

Nwankwo, J. N. and Irreclukwu, D.O. 1991. Problems; il Environmental Pollution and Control in Nigenat Petroleun Industry. SPE Conference Procectint:$102-107$.

Odu, C.T.J. 1981. Proceedings from Seminar on: $11 \mathrm{k}$ Petroleum Industry and the Nigeria Cnvirommcom V1. 143-152.

Toogood, J.A. and Rowell, M. I., 1977. Reclamation Experiments in the lields in Reclamalion of Agricultural Soil after Oil Spill. Part 1: Resteach, ! A. Toogood Edition. $34-64$. 